\title{
EU environmental law and policy post-Brexit: models for engagement between the EU27 and the UK RODERIC O'GORMAN
}

Dublin City University, Ireland

\begin{abstract}
The UK's departure from the EU will have significant impact on the existing EU environmental protection regimes. This article examines the possible options for the new relationship between the EU27 and the UK and how the environment might be protected under this. This is done through an analysis of how environmental law is dealt with under the EU's existing relationship models with non-member states. These models are examined in conjunction with the negotiating lines that have been set down by both the UK and $E U$ to see which is most politically feasible, and what impact it will have on how the EU protects the environment.
\end{abstract}

Keywords: Brexit; environmental law; climate change law; no-deal; EU law

\section{Introduction}

Just ust as in all other fields, the departure of the UK from the EU is going to have a major impact on environmental law and policy, both in that country and across the remaining 27 Member States. The transnational nature of EU law and its ability to maintain coherence in the legal regimes of all the Member States has represented an unprecedented means of setting and achieving environmental goals. The unified nature of this system, and the various thematic environmental legal regimes established through it, will now be diminished, irrespective of claims by Environment Secretary Michael Gove about the prospect of a 'Green Brexit'.'

There has already been significant commentary about the potential negative impacts of Brexit for UK environmental law. ${ }^{2}$ As the March 2019 departure deadline draws closer, it is appropriate that consideration is also given to the possible post-Brexit environmental

1 'New Environmental Protections to deliver a Green Brexit' (Press Release, Department for Environment, Food and Rural Affairs, 12 November 2017) <www.gov.uk/government/news/new-environmentalprotections-to-deliver-a-green-brexit>.

2 Maria Lee, 'Accountability for Environmental Standards after Brexit' (2017) 19(2) Environmental Law Review 89-92; Colin T Reid, 'Brexit and the Future of UK Environmental Law' (2016) 34(4) Journal of Energy and Natural Resources Law 407-15; Chris Hilson, 'The Impact of Brexit on the Environment: Exploring the Dynamics of a Complex Relationship' (2017) 7 Transnational Environmental Law 1-25. Lee outlines some potential (though it is submitted here, unlikely) upsides for the UK in moving away from the EU approach to environmental regulation which, he argues, is centred around the needs of the Internal Market: Robert Lee, 'Always Keep a Hold of Nurse: British Environmental Law and Exit from the European Union' (2017) 29 Journal of Environmental Law 155-64. 
regime that will exist between the UK and the EU27 and how this can best maintain the coherence of existing EU environmental norms. Any measures that address environmental law in the new relationship will operate within the wider legal and institutional arrangements that will be agreed. In order to better understand the potential options for the future relationship, this article considers the existing legal frameworks that the EU has entered into with non-member states, and the environmental law implications of each of these.

Section 2 examines the types of legal relations that the EU has formed with third countries: European Free Trade Area (EFTA) membership combined with bilateral agreements (the Swiss approach); the European Economic Area (EEA) Agreement model; third-country membership of the EU's Customs Union; Association Agreements; trade relationships based on the Common Commercial Policy (CCP); the EU's express treaty-making power in the area of the environment; and the European Neighbourhood Policy (ENP). The key characteristics and institutional arrangements of each are described, as well as specific aspects related to environmental policy, using examples of individual agreements where appropriate. While some of these models have already been explicitly ruled out by the British government, it is submitted that the continued lack of clarity on the present Prime Minister's preferences on a post-Brexit deal, the uncertainty surrounding what would be acceptable in the Conservative Party and the realistic possibility that the final negotiations may be undertaken by a Labour government after another general election justify discussing all potential options.

Notwithstanding these uncertainties, broad parameters of the future relationship between the EU and the UK have been sketched by the UK government and the EU negotiators. In light of these, Section 3 outlines what type of new arrangement might be politically feasible and the extent to which it would allow for the maintenance of the consistency of the EU's environmental regime. ${ }^{3}$ Consideration is also given to the coherency of this regime in the event of a 'no-deal' scenario.

\section{EU-third-country relationships in the field of environmental law}

The approach to how the EU interacts with third countries has evolved over time. ${ }^{4}$ Emerson has identified 13 different sets of graduated arrangements regulating the EU's relationship with neighbouring countries. ${ }^{5}$ This section considers the structure of relationships between the EU and contiguous states, near-neighbours, and industrialised non-neighbourhood states, with a focus on how environmental issues are addressed in these relationships.

\subsection{European Free Trade Agreement membership combined With bilateral AGREEMENTS WITH THE EU (THE SWISS MODEL)}

Founded in 1960, the EFTA is an intergovernmental organisation, comprising four states: Iceland, Liechtenstein, Norway and Switzerland. ${ }^{6}$ The four members form a free trade area, and the EFTA negotiates free trade agreements with third countries on their behalf.

3 While the fields of agriculture and fisheries have significant impacts on the environment, they are omitted from the scope of this article due to the particularly unique legal provisions around the EU's Common Agricultural Policy and the Common Fisheries Policy. As such, the focus of this article is legal measures related to the environment, climate change and sustainable development.

4 Panos Koutrakos, EU International Relations Law (2nd edn, Hart 2015) 359.

5 Michael Emerson, 'Just Good Friends? The European Union's Multiple Neighbourhood Policies' (2011) 46(4) The International Spectator 45-62, 45.

6 Convention Establishing the European Free Trade Association (Stockholm, 4 January 1960). 
Only one of the four - Switzerland - is not also a signatory of the EEA Agreement (discussed in Section 2.2 below), having voted against membership in a referendum in 1992. While Switzerland shares a free trade area with the EFTA and EU states, it is not participating in the EU Internal Market. As a consequence, it only has limited access in the area of free movement of goods under bilateral agreements negotiated with the EU. ${ }^{7}$ And it is also outside of the Customs Union. As with the EEA states, Switzerland can conclude trade agreements with non-EU states.

Due to its rejection of EEA membership, each element of EU-Swiss legal relations has to be negotiated on a bilateral basis. There are over 100 such agreements and, while there is no internalised obligation within Swiss law to adhere to these, the risk of a retaliatory blockage of access to free movement of goods by the EU in the event of noncompliance means that, in reality, Switzerland chooses to align itself with many EU laws. ${ }^{8}$ This alignment is based on the principle of equivalence of law. ${ }^{9}$ The arrangement lacks the supervisory and dispute resolution institutional structures present under the EEA Agreement. The sole EFTA membership model has been criticised due to the perceived 'fragility' of the bilateral approach of Switzerland. ${ }^{10}$ This criticism is reflected in the efforts by the EU to reform the manner in which legal relations between the EU and Switzerland operate, with a particular focus on each agreement being interpreted in conformity with the case law of the Court of Justice of the European Union (CJEU). ${ }^{11}$ Similarly, only three of the bilateral agreements are dynamic, to the extent that the agreements are updated as EU law changes. ${ }^{12}$

\subsubsection{Swiss-EU relationship and environmental law and policy}

Switzerland is engaged in environmental cooperation with the EU on a number of grounds, primarily on the basis of the bilateral agreements such as the Agreement on Air Transport (addressing noise emissions) and the Agreement on the Carriage of Goods and Passengers by Rail and Road (placing environmental taxes on heavy road haulage). ${ }^{13}$ The influence of the EU in terms of the environment can also be seen with pieces of EU legislation being substantially mirrored within domestic law, such as the Chemicals Ordinance on Protection against Dangerous Substances and Preparations, which significantly copies the EU REACH Regulation on chemicals. ${ }^{14}$ A recent agreement will see the emissions trading systems of the EU and Switzerland being linked. ${ }^{15}$

7 Alternatives to Membership: Possible Models for the United Kingdom Outside the European Union (Foreign and Commonwealth Office, March 2016) 26.

8 Ibid. The authors note particular alignment in the fields of competition law, state aid and environmental regulation.

9 Sieglinde Gstöhl and Christian Frommelt, 'Back to the Future? Lessons of Differentiated Integration from the EFTA Countries for the UK's Future Relations with the EU’ (2017) 6(4) Social Sciences 1-17, 2.

10 Ciarán Burke, Ólafur Ísberg Hannesson and Kristin Bangsund, 'Life on the Edge: EFTA and the EEA as a Future for the UK in Europe' (2016) 22(1) European Public Law 69-96, 95, fn 120.

11 Christa Tobler, 'One of Many Challenges after "Brexit": The Institutional Framework of an Alternative Agreement - Lessons from Switzerland and Elsewhere?’ (2016) 23 Maastricht Journal of European and Comparative Law 575-94, 578, 581.

12 Ibid 590-1.

13 Federal Office for the Environment, 'Relations between Switzerland and the EU in the Area of the Environment' <www.bafu.admin.ch/bafu/en/home/topics/international-affairs/organisations/relationsbetween-switzerland-and-the-eu-in-the-area-of-the-envi.html $>$.

14 Ondřej Filipec, REACH Beyond Borders: Europeanization Towards Global Regulation (Springer 2017) 122.

15 'EU and Switzerland Sign Agreement to Link Emissions Trading Systems', European Commission <https://ec.europa.eu/clima/news/eu-and-switzerland-sign-agreement-link-emissions-trading-systems_en>. 
Unlike EFTA-EEA states, Switzerland is unable to submit formal comments during the drafting stage of EU legislation, limiting its capacity to influence the final content. However, Swiss representatives do attend informal meetings of EU environmental ministers. Switzerland has also made financial contributions to the 2004 and 2007 accession states in order to improve their national infrastructure on a number of headings, including the environment. ${ }^{16}$

\subsection{The European Economic Area Agreement}

The EEA Agreement, signed at the Treaty of Oporto in 1991, allows three of the four EFTA states (Iceland, Liechtenstein and Norway) to participate in the EU's Internal Market. EU legislation relating to the Internal Market, research and development policy, social policy, education, consumer protection and environmental protection is incorporated into the EEA Agreement and is therefore applicable within those three states. ${ }^{17}$ As EU legislation in these areas changes, the EEA Agreement is continuously updated through decisions of the EEA Joint Committee, one of the institutions established to oversee the implementation of the Agreement. These EEA Acts ensure the applicability of EU law in the EEA states. ${ }^{18}$ The EEA Joint Parliamentary Committee undertakes scrutiny of decisions taken by the Joint Committee.

The EFTA Surveillance Authority mirrors the European Commission's role in ensuring that states abide by their obligations under the Agreement. It can undertake investigations of potential breaches and initiate an action against one of the component states at the EFTA Court. The EFTA Court rules on infringement actions brought either by the Surveillance Authority or another signatory state against a signatory state. It has competence to hear appeals against decisions taken by the Surveillance Authority and can give advisory opinions about the interpretation of the EEA Agreement. Unlike the CJEU, the EFTA Court does not have the power to impose a fine on states. EEA legislative measures within EEA states do not enjoy supremacy and direct effect in the same way as EU law within Member States, but there are three means of achieving similar ends: the obligation on the states to conform to their interpretation, the doctrine of state liability and Protocol 35 to the EEA Agreement (which states that in the event of a clash between EEA rules and other statutory provisions, the state undertakes to introduce a statutory provision to allow the EEA rules). ${ }^{19}$

\subsubsection{The European Economic Area Agreement and environmental law and policy}

The elements of environmental law covered by the EEA Agreement are primarily set out in Annex XX (Environment), while Annex II (Technical Regulations, Standards, Testing and Certification) also contains a section on environmental protection which enumerates a significant amount of applicable legislation. Annex XX also lists a number of pieces of EU environmental legislation which are specified as not being covered by the EEA Agreement, encompassing both legislation in existence at the time the agreement was signed and new laws subsequently passed. These exclusions cover broad areas such as

\footnotetext{
16 Federal Council, 'Switzerland's Contribution to an Enlarged EU' <www.erweiterungsbeitrag.admin.ch/erweiterungsbeitrag/en/home.html>.

17 Damien Chalmers, Gareth Davies and Giorgio Monti, European Union Law: Text and Materials (3rd edn, Cambridge University Press 2014) 31.

18 'How EU Acts Become EEA Acts and the Need for Adaptations', Note by Subcommittee V on Legal and Institutional Questions, EEA Standing Committee of the EFTA States, Ref 1113623 (23 May 2013).

19 Burke et al (n 10) 79-80.
} 
wildlife protection, some water quality rules, radiation control and the Kyoto Protocol. ${ }^{20}$ As such, the listed legislation is not binding in the states that have signed up to the EEA Agreement.

While EFTA-EEA states do not have the capacity to directly amend draft regulations and directives through the Council of Ministers and the European Parliament, it has been noted that they can bring some influence to bear on the shaping of EU legislation through the submission of written comments on draft documents and participation in expert groups of the Commission or in comitology committees. ${ }^{21}$ A case study published by the EFTA outlines the interactions that it had with the EU during the drafting of the REACH Regulation on chemicals, ${ }^{22}$ comprising a series of engagements over a six-year period including meetings of ministers and of experts, as well as written responses to the EU White Paper and successive drafts. ${ }^{23}$ While acknowledging the difficulty in measuring any specific EFTA impact due to the large number of other stakeholders involved, it notes that one EFTA priority - substituting dangerous substances for less dangerous ones where possible - is included in the legislation and another - the placing of a duty of care on manufacturers - is referred to in the Regulation's preamble. ${ }^{24}$ The EEA states must also make contributions to the 'EEA and Norway Grants' scheme, which provides funding for a number of EU beneficiary states to undertake projects under a number of headings, including the environment. ${ }^{25}$

\subsection{CUSTOMS UNION MEMBERSHIP}

The EU Customs Union includes the 28 Member States, along with some territories of the UK which are not part of the EU (Isle of Man, Guernsey, Jersey, Akrotiri and

20 Council Directive 76/160/EEC of 8 December 1975 on the quality of bathing water (The Bathing Water Directive) [1976] OJ L 31/1; Council Decision 77/795/EEC of 12 December 1977 establishing a common procedure for the exchange of information on the quality of surface fresh water in the Community [1977] OJ L 224/29; Council Directive 78/659/EEC of 18 July 1978 on the quality of fresh waters needing protection or improvement in order to support fish life [1978] OJ L 222/1; Council Directive 79/409/EEC of 2 April 1979 on the conservation of wild birds (The Birds Directive) [1979] OJ L 103/1; Council Directive 79/923/EEC of 30 October 1979 on the quality required of shellfish waters [1979] OJ L 281/47; Council Directive 92/43/EEC of 21 May 1992 on the conservation of natural habitats and of wild fauna and flora (The Habitats Directive) [1992] OJ L206/7; Council Directive 96/29/Euratom of 13 May 1996 laying down basic safety standards for the protection of the health of workers and the general public against the dangers arising from ionising radiation [1996] OJ L 159/1; Council Regulation (EC) No 338/97 of 9 December 1996 on the protection of species of wild fauna and flora by regulating trade therein [1997] OJ L 61/1; Council Decision 2002/358/EC of 25 April 2002 concerning the approval, on behalf of the European Community, of the Kyoto Protocol to the United Nations Framework Convention on Climate Change and the joint fulfilment of commitments thereunder [2002] OJ L 130/1; Council Directive 2003/122/Euratom of 22 December 2003 on the control of high-activity sealed radioactive sources and orphan sources [2003] OJ L 346/57; Decision No 280/2004/EC of the European Parliament and of the Council of 11 February 2004 concerning a mechanism for monitoring Community greenhouse gas emissions and for implementing the Kyoto Protocol [2004] OJ L 9/1; Directive 2006/7/EC of the European Parliament and the Council of 15 February 2006 concerning the management of bathing water quality [2006] OJ L 64/37; Directive 2006/44/EC of the European Parliament and of the Council of 6 September 2006 on the quality of fresh waters needing protection or improvement in order to support fish life [2006] OJ L 264/20; Council Directive 2006/117/Euratom of 20 November 2006 on the supervision and control of shipments of radioactive waste and spent fuel [2006] OJ L 337/21.

21 See Gstöhl and Frommelt (n 9) 10.

22 Regulation (EC) No 1907/2006 of the European Parliament and of the Council on Registration, Evaluation, Authorisation and Restriction of Chemicals [2006] OJ L396/1.

23 'Decision Shaping in the European Economic Area' (EFTA Bulletin 1/2009, Brussels 2009) 26-7.

24 Ibid 26.

25 <https://eeagrants.org> 
Dhekelia) and Monaco. These states have abolished internal tariffs between them and have agreed to charge the same external tariffs on goods entering the Customs Union. Beyond the removal of customs duties, the key benefit from membership of the Customs Union is that goods are not subject to quotas, checks and inspections for safety or routine customs processes such as providing customs declarations. ${ }^{26}$ Nor do goods have to comply with burdensome Rules of Origin, which is of particular importance in the context of products made from a number of components. ${ }^{27}$

The EU has also entered into a Customs Union with Turkey, Andorra and San Marino. As these non-EU states are now bound by the EU's common external tariff, they can only enter into subsequent free trade agreements with third countries which comply with the EU's external tariff regime. ${ }^{28}$ Linked to this, where the EU enters into a trade agreement with a third country, the non-EU Customs Union member must permit the goods of that third country to enter its territory, but has to negotiate separately the entry of its goods into the third country.

In terms of market size, the 1996 Customs Union Agreement (CUA) with Turkey is the most significant CUA which the EU has entered into. ${ }^{29}$ It requires Turkey to apply the EU common external tariff to the majority of industrial products and also to the industrial components of processed agricultural goods. ${ }^{30}$ Trade in primary agricultural products is excluded. ${ }^{31}$ The agreement provides for an informal right of consultation with Turkey when the EU draws up new legislation relevant to the Customs Union. ${ }^{32}$ Turkey is also to be informed of any decision to alter the EU's Common Customs Tariff. ${ }^{33}$ The overall implementation of the Agreement is overseen by a Customs Union Joint Committee. ${ }^{34}$ Its role is primarily one of providing recommendations and options about the proper functioning of the Customs Union. ${ }^{35}$

\subsubsection{Customs Union and environmental law and policy}

Within their wider role, customs officials undertake measures related to the environment, including controlling import of exotic species, rare timber and confirming that requirements surrounding the live transportation of animals are met. ${ }^{36}$ They ensure the products coming into the EU meet the particular environmental requirements across a broad range of areas such as chemicals, ozone-depleting substances, fluorinated greenhouse gases, endangered species and waste. ${ }^{37}$ Full membership of the Customs Union thus requires a non-member state to be compliant with a significant range of environmental regulations and directives.

26 Future Customs Arrangements: A Future Partnership Paper (HM Treasury, HM Revenue \& Customs, and Department for Exiting the European Union, 15 August 2017) 6.

27 Alternatives to Membership (n 7) 10.

28 Ibid 29.

29 Decision No 1/95 of the EC-Turkey Association Council of 22 December 1995 on implementing the final phase of the Customs Union (96/142/EC) [1996] OJ L 35/01.

30 Evaluation of the EU-Turkey Customs Union (Report No 85830-TR, World Bank, 28 March 2014).

31 Article 2.

32 Article 55.

33 Article 14.

34 Article 52.

35 Steve Peers, 'Living in Sin: Legal Integration under the EC-Turkey Customs Union' (1996) 7 European Journal of International Law 411-30, 420.

36 The EU Customs Union: Protecting People and Facilitating Trade (European Commission Directorate-General for Communication 2014) 3.

37 <http://trade.ec.europa.eu/tradehelp/environmental-requirements> 


\subsection{AsSOCiATION AgREementS}

The authority to negotiate an Association Agreement with other states or international organisations has been open to the EU since the Treaty of Rome and is now provided for in Article 217 Treaty on the Functioning of the European Union (TFEU). The provision itself is vague as to what Association Agreements should cover, other than that they involve 'reciprocal rights and obligations, common action and special procedure'. ${ }^{38}$ This lack of detail on what they contain has led Association Agreements to being described as 'formal frameworks for privileged relations without strict rules as to the possible substantive scope of those relations. ${ }^{39}$ A range of differently titled legal agreements have sprung from this provision including Association Agreements, Europe Agreements, Stabilisation and Association Agreements, and Cooperation and Partnership Agreements. Indeed, two of the set of legal arrangements already addressed in this article, the EEA and the EU-Turkey Customs Union, are both formed on the basis of Association Agreements. ${ }^{40}$

Association Agreements are often undertaken with an expectation that they will lead to future membership of the EU. ${ }^{41}$ However, they do not always provide a path to accession and can be used as an alternative to provide a preferential relationship with a state that is structurally unprepared or even unwilling to join the EU. ${ }^{42}$ Association Agreements will contain provisions for the creation of an institutional structure around the agreement to ensure its implementation, with a council, committee and often a parliamentary assembly, each made up of equal representation from the EU and the signatory state. ${ }^{43}$

\subsubsection{Environmental provisions in Association Agreements}

Association Agreements may contain environmental cooperation and integration clauses. ${ }^{44}$ The Association Agreement of 2014 between the EU and Moldova constitutes a recent example. ${ }^{45}$ As with all Association Agreements in the EU's neighbourhood, it constitutes a deep and comprehensive free trade agreement (DCFTA), ${ }^{46}$ with its main legal base in Article 217 TFEU. ${ }^{47}$ Two of the Association Agreement's chapters are of particular relevance to environmental protection. Chapter 16 on the Environment states that the EU and Moldova will 'develop and strengthen their cooperation on environmental issues, thereby contributing to the long-term objective of sustainable

38 Article 217 TFEU.

39 Koen Lenaerts and Eddy De Smijter, 'The European Community's Treaty Making Competence' (1996) 16 Yearbook of European Law 1-57, 17.

40 Koutrakos (n 4) 380.

41 Lenaerts and De Smijter (n 39) 20.

42 Ibid 19.

43 Ibid 16.

44 Gracia Marín Durán and Elisa Morgera, Environmental Integration in the EU's External Relations: Beyond Multilateral Dimensions (Bloomsbury 2012) 2.2.

45 Association Agreement between the European Union and the European Atomic Energy Community and their Member States, of the one part, and the Republic of Moldova, of the other part [2014] OJ L 260/4.

46 Article 1.2(g).

47 Council Decision 2014/492/EU of 16 June 2014 on the signing, on behalf of the European Union, and provisional application of the Association Agreement between the European Union and the European Atomic Energy Community and their Member States, of the one part, and the Republic of Moldova, of the other part [2014] OJ L 260/1. The Decision also cites Article 37 TEU as a legal base. With respect to Section 2.7 below, it is relevant to note that while there are two brief references to the ENP in the Preamble to the Agreement, but there is no reference to Article 8 TEU as regards legal base. 
development and greening the economy'. ${ }^{48}$ Fourteen topical areas are listed for cooperation. ${ }^{49}$ Chapter 17 on Climate Change lists the areas where the parties should cooperate in this field. ${ }^{50}$ Each chapter contains an article stating that Moldova will undertake approximation of its legislation to the EU Acts and international instruments referred to in annexes to the Agreement (Articles 91 and 97 respectively). Between the two annexes, 29 directives and regulations are listed, covering broad areas such as, inter alia, chemicals regulation, nature protection, environmental governance, air quality, water quality and climate. ${ }^{51}$ Instead of a requirement to implement each piece of legislation in total, the Annex sets out which specific provisions need to be harmonised by Moldova and outlines a timeframe within which this must take place for each legislative act.

The Agreement also contains a chapter on Trade and Sustainable Development. ${ }^{52}$ Within this, a range of sub-categories is addressed, including multilateral environmental agreements (referencing the UN Framework Convention on Climate Change and Kyoto Protocol), ${ }^{53}$ biological diversity, ${ }^{54}$ and sustainable management of forests and trade in forest products. 55 Significantly, provision is made for the establishment of a Trade and Sustainable Development Subcommittee which will oversee the implementation of this chapter, including any cooperative activities undertaken. ${ }^{56}$ A procedure is established whereby either party may seek consultations with the other regarding any matter arising under the Trade and Sustainable Development chapter by delivering a written request to the contact point of the other party. ${ }^{57}$ If the consultations do not address the matter, the party can seek to have a panel of experts convened to address the issue. ${ }^{58}$ The panel produces a report with findings of fact and recommendations. The parties then discuss what measures need to be taken, in light of the panel of experts' report. ${ }^{59}$

\subsection{Relationship based on the Common Commercial Policy}

The CCP represents the EU's trade with third countries, based on the common external tariff. Since the Lisbon Treaty, Article 3(e) TFEU states that the CCP remains an exclusive competence of the EU. Article 207 TFEU sets out the parameters of the CCP, and outlines a special procedure for the adoption of agreements based on the CCP, as an exception to the process for ratifying international agreements outlined in Article 218 TFEU. The exercise of the CCP and agreements made based on it must be done in a manner compatible with the EU's internal powers, including the environment. ${ }^{60}$

\footnotetext{
48 Article 86.

49 Article 87

50 Article 93.

51 Annex XI, Annex XII.

52 Chapter 17.

53 Article 366

54 Article 368

55 Article 369

56 Article 376(2-3).

57 Article 378(2).

58 Article 379(1).

59 Article 379(7), (8).

60 Marise Cermona, 'External Relations and External Competences of the European Union: The Emergence of an Integrated Policy' in Paul Craig and Grainne De Búrca (eds), The Evolution of EU Law (2nd edn, Oxford University Press 2011) 217-68, 229.
} 


\subsubsection{Bilateral free trade agreements and the environment}

The free trade agreement concerning goods, services and establishment entered into between the EU and South Korea is an example of an EU agreement which relies on Article 207 TFEU as one of its legal bases. ${ }^{61}$ The fact that it covered a broad range of areas, including intellectual property rights, competition and governance, and contained significant provisions on environmental and labour standards means that it is classified as a DCFTA, though, unlike the agreement with Moldova, this description is not clearly stated in the text. ${ }^{62}$ The agreement incorporates a significant number of environmental concerns within the chapter on Trade and Sustainable Development. ${ }^{63}$ The regulatory divergence provided by a free trade deal is recognised as each party may 'establish its own levels of environmental and labour protection' and 'adopt or modify accordingly its relevant laws and policies'. ${ }^{64}$ Article 13.11 states a commitment to cooperate on traderelated aspects of environmental (and social) policy, with the fields of such cooperation outlined in Annex 13 of the agreement. ${ }^{65}$ A Committee on Trade and Sustainable Development is established to oversee the implementation of this chapter.

More recently, a broad free trade area between the EU and Canada was established through the signing of the Comprehensive Economic and Trade Agreement (CETA) in 2017. ${ }^{66}$ Like the agreement with South Korea, it also relies on Article 207 TFEU as one of its legal bases. ${ }^{67}$ It also features a chapter on Trade and Sustainable Development (chapter 22) but, in contrast to the South Korean agreement, there is a full chapter entitled Trade and Environment (chapter 24), a reflection of the fact that the EU's environmental competence provision in Article 192(1) TFEU is also referenced as a legal base for the agreement. It is stated that the combined aim of these two chapters, along with that on Trade and Labour, is that the parties will: promote sustainable development; uphold their environmental protection objectives in a context of open and free trade; enhance enforcement of their respective environmental law; and promote public consultation and participation in the discussion of sustainable development issues. ${ }^{68}$

The Trade and Environment chapter recognises that each state may set its own environmental priorities, establish its own levels of environmental protection, and adopt its laws and policies accordingly and in a manner consistent with any multilateral

61 Free Trade Agreement between the European Union and its Member States, of the one part, and the Republic of Korea, of the other part [2011] OJ L 127/6; Council Decision of 16 September 2010 on the signing, on behalf of the European Union, and provisional application of the Free Trade Agreement between the European Union and its Member States, of the one part, and the Republic of Korea, of the other part [2011] OJ L $127 / 1$.

62 Koutrakos (n 4) 380.

63 Articles 13.12.3-4; 15.2.1(e).

64 Article 13.3.

65 These fields include: cooperation in international fora responsible for social or environmental aspects of trade; cooperation to promote the ratification of multilateral environmental agreements with an impact on trade; exchange of views on the trade impact of environmental regulations; cooperation on trade-related aspects of the current and future international climate change regime; and cooperation on trade-related aspects of biodiversity, promoting sustainable fishing and tackling deforestation.

66 Council Decision (EU) 2017/37 of 28 October 2016 on the signing on behalf of the European Union of the Comprehensive Economic and Trade Agreement (CETA) between Canada, of the one part, and the European Union and its Member States, of the other part [2017] OJ L 11/1.

67 Comprehensive Economic and Trade Agreement (CETA) between Canada, of the one part, and the European Union and its Member States, of the other part [2017] OJ L 11/23.

68 Article 21.1.3(a)-(e). 
environmental agreements to which it is a signatory. ${ }^{69}$ It also contains a statement that it is inappropriate for state parties to encourage trade or investment by weakening levels of protection afforded in environmental law. ${ }^{70}$

Institutional structures, similar to those in the Association Agreement with Moldova, in the form of a Committee on Trade and Sustainable Development are established and charged with responsibility for the implementation of the chapters on Trade and Sustainable Development, Trade and Labour, and Trade and Environment. ${ }^{71} \mathrm{~A}$ process for resolution of disputes about issues covered in the Trade and Environment chapter is outlined, comprising an initial consultation on the disputed issue between the parties, ${ }^{72}$ followed by referral to a panel of experts for a decision. ${ }^{73}$ The panel makes findings of fact and a determination which is communicated to the parties. ${ }^{74}$ If it determines that a party has not conformed with its obligations, the parties must engage in discussions to take necessary measures or agree a mutually acceptable plan to address the issue. ${ }^{75}$

\subsection{EXPRESS TREATY-MAKING POWER IN THE AREA OF THE ENVIRONMENT}

Since the Single European Act and the addition of what are today Articles 191 and 192 TFEU, the EU has had an express competence to conclude treaties with third parties in the field of the environment. ${ }^{76}$ The use of Article 192 TFEU as the sole legal base for signing international environmental agreements has been challenged before the CJEU a number of times where the agreement in question also covered trade issues and allegedly required Articles 192 and 207 TFEU as a joint legal base. The key significance here is the special procedure required for agreements adopted under Article 207 TFEU, as an exception to the general rules for international agreements under Article 218 TFEU.

When the EU signed the Cartagena Protocol (Convention on Biological Diversity), the decision approving this was adopted under Article 191 TFEU. The Commission argued for a joint legal base consisting of Articles 191 and 207 TFEU. ${ }^{77}$ The court found that its primary objective was an environmental one, justifying the use of Article 192 as the sole legal base. ${ }^{78}$ Neither the fact that international trade agreements often had multiple objectives, nor the requirement to give the CCP a broad interpretation stopped the environment from being the core element of the Protocol, even though it could have some impacts on trade. ${ }^{79}$

The court reached the opposite conclusion in the Energy Star Agreement case, concerning an agreement between the EU and the USA regarding an energy-efficiency labelling programmes. ${ }^{80}$ While the court accepted that this would have had some positive environmental effects stemming from reduced energy consumption in more efficient

69 Article 24.3.

70 Article 24.5.

71 Article 22.4.

72 Article 24.14.

73 Article 24.15.

74 Article 24.15.10.

75 Article 24.15.11.

76 Article 191(4) TFEU: 'Within their respective spheres of competence, the Union and the Member States shall cooperate with third countries and with the competent international organisations. The arrangements for Union cooperation may be the subject of agreements between the Union and the third parties concerned.'

77 Opinion 2/00 [2001] ECR I-9713 (Caragena Protocol).

78 Ibid paras 29, 31.

79 Ibid para 40.

80 Case C-281/01 Commission v Council [2002] ECR I-12049 (Energy Star Agreement). 
machines, this was an indirect effect, compared to the direct and immediate impact on trade in office equipment. ${ }^{81}$ Subsequently, in relation to the Rotterdam Convention (on the prior informed consent procedure for certain hazardous chemicals and pesticides in international trade), the court found the commercial elements to be not purely incidental and that some of its provisions had direct and immediate effects on trade in hazardous chemicals, ${ }^{82}$ while recognising that the protection of human health and the environment was foremost in the minds of all signatories of the Convention. ${ }^{83}$ In both cases, the court annulled the contested decisions on the basis that Article 207 TFEU should have been used as a joint legal base along with Article 191 TFEU.

In light of these and other decisions, it has been argued that international agreements being only concerned with environmental matters to a degree to warrant sole reliance on the environmental legal base would be exceptional. ${ }^{84}$ The provisions do form a shared legal base for a substantial number of bilateral agreements between the EU and other organisations, but also individual states. It has already been referenced how Article 192 TFEU is one of the treaty provisions relied upon in the decision adopting CETA. However, the Council decision applying the 2017 EU-Swiss agreement to link their emissions trading systems is solely based on the same article, reflecting the primacy of environmental and climate change issues in that agreement. ${ }^{85}$

\subsection{The European Neighbourhood Policy}

The EU's interaction with 16 states on or close to its borders is governed through the ENP. The states involved are divided into the south (Algeria, Egypt, Israel, Jordan, Lebanon, Libya, Morocco, Palestine, Syria and Tunisia) and east (Armenia, Azerbaijan, Belarus, Georgia, Moldova and Ukraine). The differences in the needs of the two separate groups would see the subsequent creation of two regional-specific programmes in 20082009, discussed below. ${ }^{86}$ The ENP originated on the basis of a Commission Communication in $2004 .{ }^{87}$ However, its status was given a legal base within the EU treaties at Lisbon, where Article 8(1) TEU states:

The Union shall develop a special relationship with neighbouring countries, aiming to establish an area of prosperity and good neighbourliness, founded on the values of the Union and characterised by close and peaceful relations based on cooperation.

The positioning of the legal basis for the ENP as a separate article outside of the external action title has been noted as indicating that it is not necessarily linked to any of the specific fields outlined in that title. ${ }^{88}$

The Commission has suggested that trade relations with ENP states should be pursued in the context of DCFTAs. ${ }^{89}$ These have been achieved in the context of the

81 Ibid para 41

82 Ibid para 42.

83 Case C-94/03 Commission v Council [2006] ECR I-1 (Rotterdam Convention) para 37.

84 Ludwig Kramer, EU Environmental Law (8th edn, Sweet \& Maxwell 2015) 91.

85 Council Decision (EU) 2017/2240 of 10 November 2017 on the signing, on behalf of the Union, and provisional application of the Agreement between the European Union and the Swiss Confederation on the linking of their greenhouse gas emissions trading systems [OJ] L 322/1.

86 Cermona (n 60) 238.

87 Communication from the Commission, European Neighbourbood Policy Strategy Paper, Brussels, COM (2004) 373 final, 12 May 2004.

88 Paul Craig and Grainne De Búrca, EU Law: Text, Cases and Materials (6th edn, Oxford University Press 2015$) 340$.

89 Koutrakos (n 4) 405; see Emerson (n 5) 50. 
bilateral Association Agreements signed between the EU and Moldova, Ukraine and Georgia. Even in the absence of Association Agreements, the model of working within the ENP is seen as strongly bilateral. ${ }^{90}$ The key components of the EU's interaction with each state is outlined within an action plan which sets out that state's agenda for political and economic reforms over a three- to five-year period. ${ }^{91}$ Environmental law and policy measures feature as a section of action plans, with a focus on convergence, both with international law measures and the EU acquis. ${ }^{2}$ However, it has been recognised that the environmental elements of action plans have not been implemented very diligently, due to a range of reasons, including the fact that the environment is not a priority in the context of the ENP, the consequent unwillingness to take strong action against states not implementing their environmental commitments, and the non-mandatory language generally used in the environmental sections of action plans, making it difficult to establish if a state is implementing the measures. ${ }^{93}$

\subsubsection{Union for the Mediterranean}

The EU Member States engage with countries from the southern and eastern Mediterranean, along with the European Commission, through the Union for the Mediterranean (UfM). ${ }^{94}$ The UfM is described as an intergovernmental organisation ... to enhance regional cooperation and dialogue in the Euro-Mediterranean region'. ${ }^{95}$ It is operated by a Secretariat with a separate legal personality. ${ }^{96}$ The UfM works to complement the bilateral legal relations established by many states in the region with the EU through Association Agreements. ${ }^{97}$

Two of the six 'priority areas' identified for the UfM's work include Energy \& Climate Action and Water \& Environment. The Mediterranean Solar Plan seeks to create a common regulatory approach as regards solar energy between EU and non-EU Mediterranean states and create a regional renewable energy market, while the Depollution of the Mediterranean project works to reduce pollution of sea water. ${ }^{98}$ While there has been some progress in these areas, it has been recognised that environmental concerns do not form a central feature of the Euro-Mediterranean policies. ${ }^{99}$

\subsubsection{Eastern Partnership}

Formed in 2009, the Eastern Partnership (EaP) sees the EU engage with six eastern states - Armenia, Azerbaijan, Belarus, Georgia, Moldova and Ukraine. At the time, it was seen as a method of differentiating elements of the ENP by creating a separate entity for post-

90 Federica Bicchi, 'The Union for the Mediterranean, or the Changing Context of Euro-Mediterranean Relations' (2011) 16 Mediterranean Politics 3-19, 9.

91 The ENP Action Plans - Association Agendas for Eastern Partner Countries <https://eeas.europa.eu/headquarters/headquarters-homepage/8398/enp-action-plans_en>.

92 Oriol Costa, 'Convergence on the Fringe: The Environmental Dimension of Euro-Mediterranean Cooperation’ (2010) 15(2) Mediterranean Politics 149-68, 154.

93 Ibid 156.

94 Albania, Bosnia and Herzegovina, Egypt, Jordan, Lebanon, Mauritania, Montenegro, Tunisia, Algeria, Israel, Monaco, Morocco, Palestine, Syria, Turkey.

95 <http://ufmsecretariat.org/who-we-are/>

96 Angelos Katsaris, 'Managing Climate Change in the Mediterranean: The Union for the Mediterranean and the Challenges of Fragmentation' (2015) 20(2) Mediterranean Politics 288-94, 290.

97 Koutrakos (n 4) 400.

98 Katsaris (n 96) 289.

99 Costa (n 92) 150; Katsaris (n 96) 290. 
soviet states. ${ }^{100}$ Within these six countries, the nature of the relationship with the EU varies, with three having indicated a desire for EU membership, and the others pursuing different alignments. ${ }^{101}$

Like the UfM, the EaP is seen as primarily for the creation of bilateral relations between the EU and the six states. ${ }^{102}$ They meet with the EU in the context of annual EaP summits. The results of such bilateral engagement, primarily Association Agreements, contain the most significant measures towards improving environmental quality and addressing climate change within these states. ${ }^{103}$ Along with the principle bilateral element, the EaP also has a number of multilateral platforms. ${ }^{104}$ The Economic Integration and Convergence with EU Policies platform includes a panel addressing 'Environment and Climate Change'. 105

\subsection{Relationship models and their level of consistency with EU environmental law}

In examining the models outlined here for their ability to maintain the consistency of the EU's environmental protection regime, considerations of breadth of coverage, compliance and enforcement are paramount. Clearly, EEA membership is the only one that comes anywhere close to replicating the coverage of EU environmental law, and even that omits some of the most successful measures in the areas of nature protection and water quality. The incorporation of pieces of EU environmental law not excluded from the EEA Agreement into Annex XX on an ongoing basis as EEA Acts would ensure their applicability within the UK. While issues of environmental law do come before both the EFTA Court and Surveillance Authority, obviously these do not possess the same level of institutional enforcement capacity as exists across the CJEU and the European Commission, nor are they applying rules that benefit from supremacy over domestic legislation. Nevertheless, EEA membership represents adherence to a substantial body of EU environmental law and a sophisticated set of enforcement institutions.

This institutional element would be missing if the UK followed the Swiss model of EFTA-only membership. Also absent would be the certainty as to what legislation would apply. Rather, the requirement to negotiate individual bilateral agreements would be timeconsuming and would mean that it would be virtually impossible to create as comprehensive a system of multi-sectoral environmental protection as exists under EU law. Further, the non-dynamic nature of many of the existing agreements limits their efficacy and it is suggested that this is particularly relevant in a field such as environmental law where standards may need to be adjusted with some regularity. However, even where a bilateral agreement is not present, the close trade links between the EU and Switzerland have meant that the latter is often in a position where it must replicate EU legislation within its national law, including in fields as complex as chemical regulation. Here, the EU again is in the position of rule-setter, thus ensuring the diffusion of its environmental standards. Significantly, this situation lacks any institutional enforcement mechanism.

100 Vlad Vernygora, David Ramiro Troitino and Sigrid Vastra, 'The Eastern Partnership Programme: Is Pragmatic Regional Functionalism Working for a Contemporary Political Empire?' in Tanel Kerikmäe and Archil Chochia (eds), Political and Legal Perspectives of the EU Eastern Partnership Policy (Springer 2016) 7, 8.

101 Marge Mardisalu-Kahar, 'Preface', in Kerikmäe and Chochia (n 100) vi.

102 Ibid.

103 Hamed Alavi, 'The European Union and Protection of Environment in Eastern Partnership Countries', in Kerikmäe and Chochia (n 100) 137, 144.

104 Ibid.

105 <https://eeas.europa.eu/sites/eeas/files/work_programme_2012_13_platform2_en.pdf> 
If the UK was to maintain its membership of the Customs Union, even if only for a transitionary period, it would continue to be bound by all the EU acquis covering the Customs Union. Should it depart but subsequently seek to enter into a new bespoke CUA, it would likewise be bound in totality by that. This will require compliance with EU standards in all areas covered by the agreement and as such a substantial range of environmental laws as regards the content and manufacturing of goods would be binding upon the UK. In the event that agriculture products were included in a CUA, the environmental impact would be even broader. However, the requirement for compliance and any enforcement structures set up under the agreement would not apply beyond those tradeable goods covered.

The Association Agreements and the free trade agreements discussed here have all included some reference to environmental concerns. In the field of the environment, existing Association Agreements have required the non-EU party to harmonise its laws with listed pieces of EU environmental legislation, thus facilitating the spread of EU norms. As Association Agreements are often used as a precursor to EU membership, the desirability of this objective enables the EU to raise its requirement for what it expects of signatory states. It has been less demanding in the environmental requirements which it has negotiated into free trade agreements with states where accession is not a consideration. The goal of pre-accession Association Agreements has been to advance the process of approximating national law with EU norms. Within the free trade agreements, there has to be much greater room for regulatory divergence between the EU regime and that of the other state. This difference in approach can be seen when comparing the free trade agreements entered into with both Korea and Canada and that signed with Moldova. Both Association Agreements and free trade agreements provide a mechanism for resolving compliance issues specifically related to the environment, though the approach is primarily one of negotiation and arbitration.

Thematic cooperation on regional-specific issues with non-EU neighbouring states is encouraged under the ENP, and the environment does feature as one of these themes. While the action plans for each state form a basis for environmental improvement, the examples cited above indicate that this cooperation works best in specific project-based interactions which, while undoubtedly positive, are narrow in focus and are a long way from the broad environmental regimes that EU legislation seeks to create. The common theme in the EU's relations with states in the ENP is that they take place in the context of economic disparity, with the EU supporting specific projects, as opposed to large-scale cooperation on environmental policies. It is unlikely that the model as currently practised would work in the context of a developed economy and political system such as that of the UK.

\section{Which model for the UK's relationship with the EU?}

\subsection{WORKING BETWEEN 'RED LINES' AND 'CLOSING DOORS'}

Efforts to conceptualise the new legal relationship between the EU and the UK, and the position of environmental law and policy within this, must, for the time being at least, operate within the boundaries of the so-called 'red lines' articulated by Prime Minister Theresa May at her Lancaster House speech in early 2017.106 These self-declared prerequisites for any deal - taking back powers from the CJEU, control over immigration

\footnotetext{
106 Speech by Theresa May (Lancaster House, London, 17 January 2017) <www.gov.uk/government/speeches/the-governments-negotiating-objectives-for-exiting-the-eu-pmspeech>.
} 
policy and the pursuit of an independent trade policy - clearly limit what sort of new arrangement is possible. Nevertheless, in both the Lancaster House speech and her subsequent Florence speech, Prime Minister May stated a desire to create a comprehensive and ambitious economic partnership between the UK and the EU. ${ }^{107}$ It is significant to note that she also expressed a clear desire to go beyond the economic realm and form a new relationship in the sphere of security - 'a bold new strategic agreement that provides a comprehensive framework for future security, law enforcement and criminal justice co-operation'. 108 Such an arrangement would not match any of the existing models of how the EU engages with its neighbours and would require a new form of relationship, or at minimum a combination of some of the options outlined.

At the same time, the insistence on the 'red lines' has led Michel Barnier, the EU's chief Brexit negotiator, to state that the UK is 'closing doors' and limiting the EU's offer to a free trade agreement. ${ }^{109}$ It is clear that absolute maintenance of the current British negotiating position would lead to a comparatively restricted new relationship, solely in the field of trade. Barnier has also spoken about the EU's goals for the relationship in the specific context of environmental policy, where he linked the UK desire for an ambitious partnership to compatibility with the European regulatory model, including in the field of environmental standards. ${ }^{110}$ He specified the need for a non-retrogression clause, which would mean the maintenance by the UK of 'key pre-Brexit standards'. He cited the example of the model used in CETA, but stated it should go further. He also made reference to the need for 'effective oversight and enforcement of environmental rules'. Environmental concerns have also featured in the stance of the European Parliament, which has stated that it will only endorse a future relationship where the UK continues to meet standards set down internationally and in EU legislation in a range of fields, including climate change and the environment. ${ }^{111}$ The Parliament also stresses the need for alignment with future EU legislation in these two fields. ${ }^{112}$

Another element that has some relevance is the position of Northern Ireland within the final agreement. In the March 2018 Draft Withdrawal Text, the UK agreed that there would be no hard border between Northern Ireland and Ireland and that Northern Ireland would enjoy full alignment with the rules of the EU's Internal Market and the Customs Union until an alternative scenario was agreed. ${ }^{113}$ Interestingly, this document also states that EU environmental law relating to the control of the import, export, release, or transport within the EU of substances, materials, plants or animals listed in an Annex would apply to the UK in respect of Northern Ireland. ${ }^{114}$

107 Speech by Theresa May (Florence, 22 September 2017) <www.gov.uk/government/speeches/pms-florencespeech-a-new-era-of-cooperation-and-partnership-between-the-uk-and-the-eu $>$.

108 Ibid.

109 Speech by Michel Barnier (Hannover Messe, 23 April 2018) <http://europa.eu/rapid/pressrelease_SPEECH-18-3511_en.htm>.

110 Remarks by Michel Barnier, Green 10: 'Is Brexit a Threat to the Future of the EU's environment?', European Parliament, 10 April 2018 <http://europa.eu/rapid/press-release_SPEECH-18-3162_en.htm>.

111 European Parliament resolution of 14 March 2018 on the framework of the future EU-UK relationship (14 March 2018) 2018/2573(RSP) para 4.

112 Ibid para 35.

113 Recitals 6 and 8, Protocol on Ireland/Northern Ireland, Draft Agreement on the Withdrawal of the United Kingdom of Great Britain and Northern Ireland from the European Union and the European Atomic Energy Community (19 March, 2018).

114 Ibid Article 7. 


\subsection{A MODEL THAT FITS AND IS CONSISTENT WITH EU ENVIRONMENTAL LAW}

As the model that requires the widest adherence to EU environmental regulations outside of membership, and which provides significant enforcement mechanisms, undoubtedly EEA membership is the next best option for maintaining the coherence of $\mathrm{EU}$ environmental law. The British demand to regain control from the CJEU would be met, and signing the EEA Agreement without also entering a Customs Union would allow for the pursuit of an independent trade policy. However, EEA membership would immediately fall foul of the British goal to regain control over immigration and, indeed, the Prime Minister explicitly rejected this option in the Florence speech. While following the Swiss option of EFTA membership without acceding to the EEA Agreement would also remove the role of the CJEU and allow for an independent trade policy, it is suggested that the prospect of the UK being cast in the role of a 'rule-taker' - practically compelled to adopt EU laws while having no say in their drafting - would be vigorously resisted by Brexit advocates. ${ }^{115}$ Both EEA and EFTA-only models also involve a financial contribution from the Member States, a requirement unlikely to be welcomed considering the resentment generated in the UK on foot of its mandatory contributions to the EU budget. In light of the fact that the Swiss option has also been ruled out by the Prime Minister and is one which, as described above, the EU itself seeks to alter, it is unlikely to provide a route suitable for the UK. ${ }^{116}$

In her Florence speech, the Prime Minister also ruled out a Customs Union with the EU, a model that would significantly resolve issues in the context of the land border between Northern Ireland and Ireland. The principal issue with staying in the Customs Union is that it would radically restrict the UK's scope for a fully independent trade policy, as the UK would be bound by the EU tariffs and thus be precluded from negotiating new free trade agreements with third countries. The British Labour Party has now staked out a clearly different approach on this point, committing to continued membership of the Customs Union during the transitional period after Brexit and to renegotiating a new Customs Union arrangement following this. ${ }^{117}$ Support for at least exploring this option was also demonstrated by a strong majority in the House of Lords, which voted for an amendment that would require the government to set out what would need to be done in order to negotiate a new Customs Union, ${ }^{118}$ though a subsequent amendment to a Customs Bill to make membership of the Customs Union mandatory was narrowly rejected in the House of Commons. ${ }^{119}$ If this option is adopted, it will mean that the UK would continue to be bound by the measures outlined above in the short term. In any negotiations for a new Customs Union arrangement, Barnier's statement regarding the EU view on the European regulatory model and the place of environmental standards within it would hopefully point to the inclusion of these standards within any future customs arrangement, with suitable institutional structures to ensure compliance.

115 Tom McTague, 'Brexiteers Fear "Swiss Trap" Trade Deal' (Politico, 15 October 2018) <www.politico.eu/article/brexiteers-fear-swiss-trap-deal-for-britain>.

116 Tobler (n 11) 578, 581, 590-1.

117 Speech by Jeremy Corbyn (Coventry, 26 February 2018) <https://labour.org.uk/press/jeremy-corbyn-fullspeech-britain-brexit>.

118 Henry Mance, ‘Government Suffers Two Brexit Defeats in House of Lords’ Financial Times (London, 18 April 2018) < www.ft.com/content/fce0bc2e-4323-11e8-803a-295c97e6fd0b>.

119 Benjamin Kentish, 'Theresa May Wins Knife-edge Customs Bill Vote as Defence Minister Resigns amid Tory Rebellion' Independent (London, 16 July 2018) <www.independent.co.uk/news/uk/politics/brexit-latesttheresa-may-guto-bebb-defence-minister-customs-bill-vote-a8450356.html>. 
The March 2018 European Council guidelines on the framework for post-Brexit relations with the UK are particularly cognisant of Prime Minister May's rejection of both the Single Market and the Customs Union. In light of this, they set out an EU offer based primarily around a free trade agreement. ${ }^{120}$ The guidelines reference 'specific partnerships' in fields such as law enforcement and judicial cooperation in criminal matters, and foreign, security and defence policy. ${ }^{121}$ They also state that the new relationship should address global challenges like climate change, sustainable development and cross-border pollution, with close cooperation between the EU and UK in these areas. ${ }^{122}$ These guidelines suggest that the relationship will be no less than a free trade agreement negotiated under the CCP. It has been shown that, where the EU has already entered into such free trade agreements, they do contain environmental provisions. Again, citing Barnier's statement, there is reason for optimism that the EU will insist on the maintenance of the existing level of environmental protections being written into the agreement's provisions. ${ }^{123}$

Assuming, in light of the 'Green Brexit' comments, that the UK is serious about undertaking some structured and coherent cooperation in the field of the environment and climate change, an Association Agreement would represent a more comprehensive means of achieving this, beyond a free trade agreement. EU statements to date place great emphasis on a non-regression clause as regards environmental standards. In the context of the UK, initially at least this would be no more than recognising the status quo, as the UK should already comply with existing EU measures. A key question from the point of view of future consistency between the EU and UK regimes will be whether the EU can insist on the inclusion of an 'environmental advancement principle' to ensure a drive for continuously higher standards. ${ }^{124}$ This would leave the UK in the position of a rule-taker in the environmental field and it is highly questionable whether it would agree to this in the context of an Association Agreement. Much will hinge on whether, in the context of the new relationship, the EU actually places a high enough priority on environmental issues to insist upon a quid pro quo between these and the areas the UK places a premium on, but it is significant that the European Parliament, which must approve the final Brexit deal, has indicated support for the environmental advancement principle.

In the event that an Association Agreement is not acceptable, the UK could form its relationship with the EU in the context of a free trade agreement and looser cooperation through a new model based under the ENP - a potential 'British Isles Partnership'. While this would allow for cooperation in specified areas, it would require that this be done on a bilateral basis, thus addressing British fears about the loss of sovereignty. Such a relationship could have an environmental dimension and may be particularly useful for supporting specific cross-border environmental projects between Northern Ireland and Ireland. However, this would require changes in the EU's approach to the ENP to take account of the shared level of economic and political development and the environmental standards already existing.

One obvious mechanism for continued engagement between the EU and UK on environmental issues would be for the latter to maintain its membership of the European

120 European Council (Article 50) Guidelines on the Framework for the Future Relationship with the UK, 23 March 2018, para 8. <www.consilium.europa.eu/media/33458/23-euco-art50-guidelines.pdf>.

121 Para 13.

122 Para 9.

123 Robert Lee (n 2) 161.

124 Charlotte Burns, Andrew Jordan and Viviane Gravey, 'UK Environmental Policy Post-Brexit: A Risk Analysis' (Report for Friends of the Earth, Brexit and Environment, March 2018) 39. 
Environment Agency. Established in the early 1990s, the European Environment Agency was tasked with providing Member States with 'objective, reliable and comparable information at European level enabling them to take the requisite measures to protect the environment, to assess the results of such measures and to ensure that the public is properly informed about the state of the environment'. ${ }^{125}$ All Member States of the EU are members, along with the three EEA states. ${ }^{126}$ Switzerland's membership is governed by a bilateral agreement with the EU. ${ }^{127}$ The European Environment Agency can also engage with third countries and international organisations, under the heading of 'International Cooperation'. ${ }^{128}$ Of particular relevance here is the capacity for non-EU countries to join the Agency and regional cooperation with states who are not members or partnered with it, but which 'cover geographical areas with close or transboundary geographic or geo-political links to the EU, and where there are well-defined EU policies'. ${ }^{129}$ Turkey, which joined as a member in 2003, offers a model for the UK in that it demonstrates a working membership outside the context of the EU, EEA or the EFTA. ${ }^{130}$ As the Agency is primarily about the compilation of information on the environment and performs no regulatory, legislative or adjudicative functions, it is submitted that retaining full membership would not cross any of the red lines established by the British Prime Minister. Such a development would allow the Agency to continue to receive environmental information from the UK, maintaining the range of its data sources.

\subsection{NO-DEAL SCENARIO}

While this article focuses on the diverse options for the future relationship between the EU and UK, the possibility of there being no clear agreement has to be at least considered. The Prime Minister's statement in the Lancaster House speech that 'no deal for Britain is better than a bad deal for Britain' has continued to remain a mantra for her government. ${ }^{131}$ The consequences of such a situation would be immense, with major implications for the environment as in all other fields. In the UK, there would be a need to immediately enhance its regulatory capacity to meet the gap created by the removal of EU equivalents in the event of a no-deal situation, compared to the possibility of equivalence or mutual recognition agreements being put in place as part of a negotiated agreement. ${ }^{132}$ As such, Brexit planning within the UK's Department for Environment, Food and Rural Affairs is progressing on the basis of a no-deal situation being a possible scenario. $^{133}$

125 Council Regulation (EEC) No 1210/90 of 7 May 1990 on the establishment of the European Environment Agency and the European Environment Information and Observation Network (1990) OJ L 120/1, Article $1(2)(a)$.

$126<$ www.eea.europa.eu/about-us/countries-and-eionet>

$127<$ www.eda.admin.ch/dea/en/home/bilaterale-abkommen/ueberblick/bilaterale-abkommen2/umwelt.html>

128 <www.eea.europa.eu/about-us/international-cooperation>

129 Ibid.

130 <www.eea.europa.eu/highlights/Ann1043764126>

131 May (n 106).

132 House of Commons Foreign Affairs Committee, 'Article 50 Negotiations: Implications of "No Deal”" (HC 1077, March 2017) para 48.

133 National Audit Office, 'Implementing the UK's Exit from the European Union: The Department for Environment, Food and Rural Affairs' (HC 647 2017-19) 15. 
It has been noted that a no-deal scenario may make a political necessity of the UK entering into more liberal trade arrangements with third countries. ${ }^{134}$ Such arrangements could necessitate reduced regulation and the lowering of environmental standards. ${ }^{135}$ This so-called 'Singapore-on-Thames' model could pose a real difficulty for the EU successfully competing for business. ${ }^{136}$ However, it has also been contended that due to the extraterritoriality of EU law - the so called 'Brussels effect' - the UK will find that in trade negotiations with third countries there will be a political requirement to align standards with those of the EU, due to its influence and market power. ${ }^{137}$ The REACH legislation, the Restriction of Hazardous Substances Directive and the EU's emissiontrading scheme have all been cited as examples of where EU norms in the form of legislation have become de facto international standards. 138 The irony that, even following a withdrawal with no replacement agreement, EU standards still impact upon the UK, would hopefully not be lost on Brexiteers.

In a no-deal scenario, and, indeed, irrespective of the nature of the UK's relationship with the EU, the UK will still be bound by the range of international environmental agreements that it has signed up to on an individual basis, most of which would also be binding within EU law. The obligations contained in these offer some prospect for the maintenance of coherence, at least initially, between the laws of the EU27 and of the UK, though international rules are weaker and enforcement mechanisms are less effective. ${ }^{139}$ The extent of these treaties is beyond the scope of this article, but have been explored in detail in a report by the UK Environmental Law Association. ${ }^{140}$

\section{Conclusion}

Although what exactly the UK desires its new relationship with the EU to be is still unclear, it is obvious that it seeks a model different to any which exist to date. Close integration on three of the four freedoms (while keeping control over the admittance of non-nationals), no scrutiny of national decisions by supra-national courts, an unencumbered ability to enter into free trade deals around the world, and a new security agreement represent an à la carte list of desires on behalf of the non-member state. The current nature of the EU's relationship with non-member contiguous neighbours falls into the category of benefits and obligations without a voice in the case of industrialised states like Norway, Switzerland and Iceland, or a supportive engagement with prospective members or non-applicant developing states through trading relationships and improving their economic and social governance. The nature of these existing relationships generally is mirrored in each case in the context of the specific field of environmental law.

134 Siyi Feng, Myles Patton, Julian Binfield and John David, “Deal” or "No Deal”? Impacts of Alternative PostBrexit Trade Agreements on UK Agriculture' (2017) 16(3) EuroChoices 27, 32.

135 Jonathan Gaventa, 'Brexit and the EU Energy Union: Keeping Europe's Energy and Climate Transition on 'Track' (E3G Working Paper, April 2017) 4.

136 Jeevan Vasagar, 'Singapore-on-Thames? This Is No Vision for Post-Brexit Britain' The Guardian (London, 24 November 2017) <www.theguardian.com/commentisfree/2017/nov/24/singapore-on-thames-postbrexit-britain-wealthy-city-state $>$.

137 Annegret Engel and Ludivine Petetin, 'International Obligations and Devolved Powers: Ploughing through Competences and GM Crops' (2018) 20(1) Environmental Law Review 16-31, 29.

138 Anu Bradford, 'The Brussels Effect' (2012) 107 Northwestern University Law Review 1-67, $26-31$.

139 Charlotte Burns, Andrew Jordan and Viviane Gravey, 'The EU Referendum and the UK Environment: The Future under a "Hard" and a "Soft" Brexit' (ESRC UK in a Changing Europe Initiative 2016) 10.

140 The UK and International Environmental Law after Brexit (Brexit and Environmental Law Series, UK Environmental Law Association, September 2017). 
The novel nature of the arrangements that the UK is seeking opens the possibility that it could look to make specific arrangements on discrete environmental issues. The $\mathrm{UK}$ is recognised as one of the EU states that has promoted strong policies to tackle climate change. ${ }^{141}$ It may well wish to continue to be linked to some of the EU's policies in this regard. This could be done through an agreement whereby it would remain part of the European Trading Scheme, or link its system to that of the EU, as Switzerland has done. ${ }^{142}$ However, the indications as to the degree of importance that the British government is placing on environmental matters is mixed. A statement from a senior civil servant in the Foreign and Commonwealth Office that ' $\mathrm{t}] \mathrm{rade}$ and growth are now priorities for all posts ... [s]ome economic security-related work like climate change and illegal wildlife trade will be scaled down' has raised concerns. ${ }^{143}$ Climate change and the environment were each only referenced once in the Prime Minister's Florence speech, the latter in the context of the future British environment and neither term featured in the Lancaster House speech. The failure to reference these issues in two speeches seen as key explanations of British goals in the negotiating process is worrying. More positively, it is worth nothing that the British Department for the Environment has hired almost 1200 new staff to deal with the volume of work created by British exit, which at least suggests an understanding of the scale of the task ahead. ${ }^{144}$ Similarly, in the Prime Minister's Mansion House speech of March 2018, she made a number of references to strong environmental protection, though this was again focused on the internal British regime post-Brexit. ${ }^{145}$

All of the scenarios outlined here represent a retreat from the existing set of environmental protection regimes. In the medium term post-Brexit, the prospect of ensuring consistency in standards and subsequent enforcement between the EU27 and British environmental systems is significantly diminished, as the UK will lack the accountability mechanisms previously provided by the European Commission and the CJEU to ensure adherence to legislative requirements. ${ }^{146}$ Within the EU itself, the UK's departure has been noted as being a potential threat to its environmental ambition in certain areas, particularly climate, with a shift in the balance of power in the Council towards states less inclined to support policies that seek continued cuts in emissions. ${ }^{147}$ At a time when coherent global and regional cooperation and ambitious action are understood as key pillars in combatting environmental challenges like climate change and transboundary pollution, there are few positives to be seen for EU environmental law across the potential post-Brexit models for relations between it and the UK.

141 Eloise Scotford and Megan Bowman, 'Brexit and Environmental Law: Challenges and Opportunities' (2016) 27(3) King's Law Journal 416-19, 418.

142 Brexit and the EU ETS (Sandbag, May 2017) 10.

143 Sam Coates, 'Climate Change and Wildlife Suffer in Race for Trade Deal' The Times (London, 10 April 2017) $<$ www.thetimes.co.uk/article/climate-change-and-wildlife-suffer-in-race-for-trade-deal-gffqtsx3r>.

144 Laura Hughes, 'UK Environment Department Hires 1,150 Staff to Deal with Brexit' Financial Times (London, 26 April 2018) <www.ft.com/content/89a441c2-4977-11e8-8ae9-4b5ddcca99b3>.

145 Speech by Theresa May (Mansion House, London, 2 March 2018) <www.gov.uk/government/speeches/pmspeech-on-our-future-economic-partnership-with-the-european-union>.

146 Maria Lee (n 2) 89.

147 Burns et al (n 124) 23; Fay Farstad, Neil Carter and Charlotte Burns, 'What Does Brexit Mean for the UK's Climate Change Act?' (2018) 89 The Political Quarterly 291-7, 294-5. 